\title{
Pemetaan Informasi Sebaran Bidang Ilmu Pada Skripsi Fakultas Matematika dan Ilmu Pengetahuan Alam Lulusan IPB University Tahun 2015 - 2019 Berdasarkan Universal Decimal Classification: Suatu Kajian Bibliometrika
}

\author{
Raden Wahyudin ${ }^{1}$ dan Abidin ${ }^{2}$ \\ Perpustakaan IPB University \\ 1 1 rayudin@apps.ipb.ac.id, ${ }^{2}$ Abidinazis123@gmail.com
}

\begin{abstract}
Abstrak
Pendahuluan. IPB-University, perguruan tinggi terkemuka di Indonesia senantiasa menghasilkan banyak penelitian dan inovasi. Karya tulis akademik berupa skripsi suatu bukti nyatanya. Namun demikian belum ada suatu kajian yang pernah memetakan hasil-hasil penelitian tersebut. Penelitian ini dilakukan untuk mengetahui: Sebaran topik penelitian, Membuat peta (create map) bidang ilmu berdasarkan standar Universal Decimal Classification, dan Memvisualisasikan peta (map) kata kunci, serta Produktivitas dosen pembimbing pada skripsi Fakultas Matematika dan Ilmu Pengetahuan Alam IPB University.
\end{abstract}

Metode Penelitian. Penelitian ini merupakan suatu kajian bibliometrik dengan metode penelitian kuantitatif, guna mendeskripsikan pemetaan informasi sebaran bidang ilmu pada skripsi Fakultas Matematika dan Ilmu Pengetahuan Alam IPB University.

Pengolahan Data Penelitian. Obyek penelitian ini adalah data skripsi Fakultas Matematika dan Ilmu Pengetahuan Alam pada pangkalan data Perpustakaan IPB University. Data diolah menggunakan Program M.S. Excel dan dikelompokkan berdasarkan standar Universal Decimal Classification. Data kata kunci dibuat File RIS (RIS File) dan dianalisis menggunakan Program VosViewer-Visualizing Scientific Landscapes 1.6.1.5 yang dikembangkan oleh Nees Jan Van Eck dan Ludo Waltman.

Hasil Penelitian. Membuktikan, topik penelitian skripsi Fakultas Matematika dan Ilmu Pengetahuan Alam IPB University lulusan tahun 2015-2019 sebanyak 3.550 judul. Peta bidang ilmu berdasarkan Universal Decimal Classification menunjukkan topik penelitian paling banyak kelas 004: "Ilmu dan Teknologi Komputer, Komputasi dan Pemrosesan data" 719 (20,25\%) judul, topik penelitian paling sedikit kelas 590: "Zoologi" 43 (1,21\%). Analisis kata kunci atau co-word menggunakan Vosviewer 1.6.1.5 pada kemunculan kata kunci minimum 5 berhasil memvisualisasikan 683 kata kunci dalam 12 gugus (cluster). Kata kunci paling banyak muncul terjadi yaitu "Ilmu dan Teknologi Komputer" 153 kali. Visualisasi Jaringan (Network Visualization) menunjukan kecenderungan (trend) topik penelitain paling banyak diminati: "Ilmu dan Teknologi Komputer" ada pada gugus (cluster) 5 dengan kekuatan tautan total (total network link) 397. Visualisasi Hamparan (Overlay Visualization) menunjukan kecenderungan (trend) tahun penelitian pernah dilakukan yaitu antara tahun 2016-2018. Visualisasi Kepadatan (Density Visualization) menunjukan kecenderungan (trend) kepadatan volume penelitian masing-masing kata kunci tersebut berpariasi. Produktivitas dosen pembimbing skripsi paling tinggi sebagai pembimbing utama ialah Imas Sukaesih Sitanggang sebanyak 79 bimbingan, sedangkan sebagai pembimbing anggota ialah Ali Kusnanto dan Budi Waryanto, jumlah bimbingan masingmasing sebanyak 42 dan 8 bimbingan skripsi.

Kata kunci : ilmu pengetahuan alam, MIP A, karya tulis akademik, skripsi, pemetaan, roadmap, penyebarluasan informasi, desiminasi, vosviewer 


\begin{abstract}
Preliminary. IPB-University, a leading university in Indonesia, always produces a lot of research and innovation. Academic writing in the form of a thesis is a real proof. However, there has been no study that has mapped the results of these studies. This research was conducted to determine: the distribution of research topics, create a map of the field of science based on the Universal Decimal Classification standard, and visualize a map of keywords, as well as the productivity of the supervisor in the thesis of the Faculty of Mathematics and Natural Sciences, IPB University.
\end{abstract}

Research Methods. This research is a bibliometric study with quantitative research methods, in order to describe the mapping of information on the distribution of knowledge in the thesis of the Faculty of Mathematics and Natural Sciences, IPB University.

Research Data Processing. The object of this research is the Faculty of Mathematics and Natural Sciences thesis data in the IPB University Library database. The data is processed using the M.S. Excel and grouped according to the Universal Decimal Classification standard. The keyword data was created in an RIS File and analyzed using the VosViewer-Visualizing Scientific Landscapes 1.6.1.5 program developed by Nees Jan Van Eck and Ludo Waltman.

Research Result. Proving that the thesis research topics of Faculty of Mathematics and Natural Sciences, IPB University graduates in 2015-2019 are 3,550 titles. Map of fields of science based on UDC showing research topics at most grade 004: "Computer Science and Technology, Computing and Data Processing" 719 (20.25\%) titles, research topics at least grade 590: "Zoology" $43(1.21 \%)$. Co-word analysis using Vosviewer 1.6.1.5 on the occurrence of a minimum of 5 keywords succeeded in visualizing 683 keywords in 12 clusters. The keyword that appears the most occurs is "Computer Science and Technology" 153 times. Network Visualization shows the trend of the most popular research topics: "Computer Science and Technology" is in cluster 5 with a total network link strength of 397 . Overlay Visualization shows a tendency the year the research was conducted, which was between 2016-2018. Density Visualization shows the tendency for the density of research volumes for each of these keywords to vary. The highest productivity of the thesis supervisor as the main supervisor is Imas Sukaesih Sitanggang as many as 79 guidance, while as member supervisors are Ali Kusnanto and Budi Waryanto, the number of guidance is 42 and 8 thesis guidance, respectively.

\section{Pendahuluan}

Penelitian ini bermula dari belum adanya suatu kajian pemetaan hasil karya tulis akademik mahasiswa (skripsi), terutama pada skripsi Fakultas Matematika dan Ilmu Pengetahuan Alam di IPB University. Penelitian ini dianggap perlu agar tergambar jelas tentang informasi sebaran jumlah topik penelitian, sebaran bidang ilmu, visualisasi peta jalan (road map), serta produktivitas dosen pembimbing pada skripsi Fakultas Matematika dan Ilmu Pengetahuan Alam IPB University lulusan Tahun 2015-2019. Alasan kurangnya infor-masi sebaran topik penelitian dan bidang ilmu bagi Mahasiswa dan Dosen pembimbing, maka penelitian ini dilakukan dengan harapan dapat membantu dalam membuat peta jalan (road map) penelitian skripsi Fakultas
Matematika dan Ilmu Pengetahuan Alam IPB University, dan menjadi informasi penting bagi pimpinan fakultas maupun departemen, serta sebagai bahan evaluasi pemetaan topik penelitian. Hasil Penelitian disampaikan dalam bentuk laporan hasil penelitian, dan berupa; Booklet visualisasi peta jalan (road map), serta Paper poster tentang hasil penelitian skripsi Fakultas Matematika dan Ilmu Pengetahuan Alam di IPB University. Penelitian dilakukan selama 5(lima) bulan mulai dari pekan kedua April sampai dengan pekan kedua Bulan September 2020. Tujuan penelitian ini untuk Memetakan sebaran infomasi jumlah topik penelitian, sebaran bidang ilmu berdasarkan Universal Decimal Classification (UDC); dan untuk 
Menampilkan visualisasi peta jalan (road map) subyek dan kata kunci, serta produktivitas dosen pembimbing pada skripsi Fakultas Matematika dan Ilmu Pengetahuan Alam IPB University lulusan Tahun 2015-2019.

\section{Kajian Pustaka}

Penelitian ini dilakukan merujuk kepada beberapa judul penelitian sejenis yang pernah dilakukan, namun berbeda pada obyek penelitian guna memperkaya khasanah kepustakaan dalam analisis data dan pembahasan.

Pertama penelitian yang berjudul "Peningkatan Layanan Data dan Informasi dalam Rangka Memenuhi Kebutuhan Informasi di Perpustakaan Perguruan Tinggi (suatu kajian deskriptif analisis terhadap 5 bunga komersial utama dan 7 bunga potensial komersil)" (Ratnaningsih \& Himawan, 2016). Kajian ini menyimpulkan bahwa: (1) Penelitian belum dilakukan secara merata terhadap masing-masing jenis dari 5 jenis bunga komersial dan 7 bunga potensial komersial karena belum adanya penelitian terkait beberapa bunga jenis tertentu; (2) Anggrek merupakan jenis bunga yang paling banyak diteliti oleh mahasiswa program sarjana (skripsi), pascasarjana (tesis), maupun doktor (disertasi); (3) Bidang yang paling banyak dikaji adalah bidang budidaya pertanian. Untuk bidang lainnya, dapat dijadikan peluang untuk dijadikan bidang penelitian; (4) Peta/mindmap terkait 5 bunga komersial dan 7 bunga potensial komersial merupakan salah satu bentuk produk perpustakaan dalam layanan data dan informasi kepada pengguna khususnya kelompok pimpinan; (5) Peta/mindmap terkait 5 bunga komersial dan 7 bunga potensial komersial dapat menjadi masukan kepada kelompok pimpinan dalam pengambilan keputusan maupun kebijakan dalam mendukung pengembangan bunga nusantara. Penelitian ini merekomen-dasikan kepada: (1) Departemen atau Program Studi perlu membuat peta jalan (road map) tentang penelitian yang dilakukan oleh para mahasiswa yang akan menyelesaikan studi di Departemen atau Program Studi tersebut.

Berdasarkan peta jalan (road map) tersebut maka penelitian mahasiswa baik program sarjana, pascasarjana, maupun doktoral dapat diarahkan untuk mendukung pengembangan ilmu pengetahuan dan teknologi khususnya yang menunjang teknologi produksi dan industri di bidang pertanian; (2) Departemen atau Program Studi dapat menawarkan topik-topik penelitian yang sesuai dengan peta jalan (road map) agar penelitian terarah dan dapat menghasilkan hasil-hasil penelitian yang dapat bermanfaat tidak saja kepada pengembangan ilmu pengetahuan dan teknologi, namun juga bagi kemajuan pertanian sehingga para petani Indonesia menyumbang kemajuan terhadap ekonomi negara.

Kedua penelitian yang berjudul "Peta Penelitian Terhadap 12 Jenis Buah Lokal Indonesia Pada Skripsi, Tesis dan Disertasi Lulusan IPB" (Ratnantingsih, Himawan, \& Saleh, 2019). Penelitian ini menyimpulkan bahwa: (1) Penelitian terkait 12 jenis buah tropika baik pada skripsi, tesis, maupun disertasi belum begitu intensif. Bahkan pada disertasi ada lima jenis buah dari 12 jenis buah lokal selama lima tahun terakhir (2012-2016) tidak ada yang meneliti; (2) Pada penelitian program sarjana (skripsi) buah yang paling banyak diteliti selama lima tahun terakhir (2012-2016) adalah buah pisang sedangkan yang paling sedikit adalah buah semangka. Pada program pascasarjana (tesis) buah yang paling banyak diteliti selama lima tahun terakhir (2012-2016) adalah buah jeruk dan paling sedikit adalah buah semangka. Sedangkan pada program doktor (disertasi) buah yang paling banyak diteliti selama lima tahun terakhir (2012-2016) adalah buah manggis, sedangkan buah alpukat, 
rambutan, pepaya, melon, dan semangka sama sekali tidak ada yang meneliti; (3) Bidang yang paling banyak dikaji adalah bidang budidaya tanaman dan teknologi agroindustri. Sedangkan bidang-bidang lainnya masih sangat berpeluang untuk dijadikan bidang penelitian. Serta merekomendasikan sebagai berikut: 1). Departemen atau Program Studi di lingkungan IPB perlu membuat peta jalan (road map) tentang penelitian yang dilakukan oleh para mahasiswa yang akan menyelesaikan studinya di Departemen atau Program Studi tersebut. Dengan peta jalan (road map) tersebut maka penelitian mahasiswa baik program sarjana, pascasarjana, maupun doktoral dapat diarahkan untuk mendukung pengembangan ilmu pengetahuan dan teknologi khususnya yang menunjang teknologi produksi dan industri di bidang pertanian, 2). Departemen atau Program Studi dapat menawarkan topik-topik penelitian yang sesuai dengan peta jalan (road map) agar penelitian terarah dan dapat menghasilkan hasil-hasil penelitian yang dapat bermanfaat tidak saja kepada pengembangan ilmu pengetahuan dan teknologi, namun juga bagi kemajuan pertanian sehingga para petani Indonesia dapat menyumbang kemajuan terhadap ekonomi negara.

Ketiga penelitian yang berjudul "Pemetaan Bidang Ilmu pada Skripsi Fakultas Peternakan IPB lulusan 20122016 sesuai Universal Decimal Classification" (Saleh, 2018). Penelitian ini menyimpulkan: (1) Diketahui bahwa bidang ilmu yang menjadi topik penelitian mahasiswa terbanyak untuk penulisan skripsinya adalah bidang ilmu pakan ternak yang terdiri dari pakan dan teknologi pakan ternak sebanyak 328 judul penelitian atau $31,1 \%$ dari seluruh skripsi dan hijauan pakan ternak sebanyak 181 judul penelitian atau $17,2 \%$ dari total skripsi; (2) Skripsi di luar bidang pakan ternak berjumlah 546 judul penelitian atau sebesar 51,8\% yang terdiri dari (diurut berdasarkan jumlah penelitian yang paling besar) pemuliaan dan genetika ternak, ternak unggas, daging, sosial ekonomi peternakan, sistem peter-nakan (farm), ternak lain lain, susu, ruminan kecil, bacteriologi, reproduksi, ruminansia besar, hasil ternak selain makanan, telur, keluarga lebah/ serangga, fisiologi, ternak kerja/ rekreasi, burung non unggas, kelinci, dan ternak babi; (3) Tiga orang dosen paling produktif sebagai ketua pembimbing skripsi adalah Dr. Irma Isnafia Arief, S.Pt, M.Si. (39 bimbingan), diikuti Muhamad Baihaqi, S.Pt, M.Sc. (36 Bimbingan), dan Prof. Dr. Ir. Cece Sumantri dan Dr. Ir. Rita Mutia, M.Agr. (dengan 30 bimbingan).

Keempat penelitian yang berjudul "Pemetaan Bidang Ilmu Pada Skripsi Fakultas Perikanan Lulusan Tahun 2014-2018 Berdasarkan Standar Universal Decimal Classification" (Saleh, 2019). Penelitian ini menyimpulkan: (1) Jumlah skripsi mahasiswa Fakultas Perikanan dan Ilmu Kelautan IPB 2014 - 2018 berjumlah 1.826 judul. terdiri atas skripsi mahasiswa Departemen BDP sebanyak 399 judul penelitian (21,85\%), Departemen MSP sebanyak 383 judul penelitian (20,97\%), Departemen THP sebanyak 374 judul penelitian (20,48\%), Departemen ITK sebanyak 357 judul penelitian (19,55\%), Departemen PSP sebanyak 313 judul penelitian (17,14\%); (2) Berdasarkan tahun kelulusan, jumlah skripsi terbanyak berada pada tahun 2017 yaitu sebanyak 287 judul, kemudian diikuti tahun 2016 dan 2018 masing-masing sebanyak 377 judul, tahun 2014 sebanyak 375 judul dan paling sedikit adalah pada tahun 2015 yaitu berjumlah 309 judul; (3) Berdasarkan kawasan keilmuan menurut UDC maka penelitian mahasiswa FPIK paling banyak adalah pada kelompok ilmu terapan yaitu sebanyak 1313 judul (71,91\%), ilmu murni sebanyak 432 judul $(23,17 \%)$, 
ilmu-ilmu sosial dan ekonomi sebanyak 86 judul $(4,71 \%)$, dan yang paling sedikit adalah yang termasuk kelompok umum yaitu sebanyak 4 judul (0,22\%); (4) Bidang yang menjadi penelitian mahasiswa FPIK terdiri dari dua kelompok besar yaitu bidang yang terkait komoditas perikanan (sebanyak 546 judul atau 29,90\%) dan bidang non-komoditas perikanan (sebanyak 1280 judul atau 70,10\%); (5) Penelitian terkait komoditas perikanan terdiri dari mengenai komoditas ikan (sebanyak 347 penelitian atau 63,55\%) dan komoditas non-ikan (sebanyak 199 penelitian atau 36,45\%); (6) Ikan lele merupakan jenis ikan yang terbanyak menjadi obyek penelitian pada kelompok penelitian tentang ikan air tawar yaitu sebanyak 64 penelitian, sedangkan ikan baung, lelawak, uceng, dan tambakan merupakan jenis ikan yang paling sedikit diteliti yaitu masing-masing hanya 1 penelitian. Sedangkan pada jenis ikan laut/payau, ikan sidat merupakan ikan yang paling banyak diteliti (21 penelitian). Ikan baronang dan swanggi merupakan ikan yang paling sedikit diteliti. Bahkan banyak ikan-ikan endemik Indonesia yang belum dijadikan obyek penelitian; (7) Pada komoditas non-ikan maka tumbuhan laut yang terdiri dari alga dan lamun menjadi obyek penelitian terbanyak yaitu sebanyak 63 penelitian, sedangkan yang paling sedikit diteliti adalah siput laut dengan 1 penelitian; (8) Penelitian terkait nonkomoditas perikanan yang paling banyak dijadikan obyek penelitian adalah bidang yang berhubungan dengan ekologi, ekosistem, pengelolaan limbah dan pencemaran air yaitu sebanyak 236 penelitian. Sedangkan yang menjadi obyek penelitian paling sedikit adalah penyakit ikan yaitu sebanyak 3 penelitian; (9) Dosen paling produktif membimbing adalah Agoes Mardiono Jacoeb dengan jumlah bimbingan sebanyak 81 mahasiswa. Jumlah ini terbagi menjadi sebagai pembimbing utama 24 mahasiswa bimbingan, dan sebagai pembimbing anggota sebanyak 57 mahasiswa bimbingan; (10) Dosen yang menjadi pembimbing utama paling banyak adalah Dietriech Geoffrey Bengen, Kukuh Nirmala, dan Nurjanah dengan jumlah bimbingan masing-masing 35 orang.

Penulisan karya ilmiah merupakan sebuah kegiatan yang wajib dilakukan di perguruan tinggi manapun di dunia. Karya ilmiah harus ditulis sesuai dengan tata cara ilmiah yaitu dengan berpedoman kepada panduan penulisan karya ilmiah.

Melalui karya ilmiah masyarakat perguruan tinggi dapat berkomunikasi dan mengetahui perkembangan dalam bidang ilmu yang ditekuninya. Salah satu jenis karya ilmiah di perguruan tinggi adalah skripsi. Skripsi adalah sebuah karya tulis akademik yang ditulis seorang mahasiswa sebagai salah satu syarat kelulusan pada program strata 1 (S-1) setelah mahasiswa tersebut menyelesaikan 135 SKS. Selama dalam proses penulisan skripsi mahasiswa biasanya dibimbing oleh dosen pembimbing yang ahli di bidangnya.

Batasan lain juga ada yang menyebutkan bahwa "skripsi merupakan karya tulisan ilmiah berdasarkan hasil penelitian lapangan dan atau studi kepustakaan yang disusun mahasiswa sesuai dengan bidang studinya sebagai tugas akhir dalam studi formalnya di Perguruan Tinggi" (Helmi, 2014). Dengan demikian maka skripsi merupakan sebuah tugas akhir yang dipersyaratkan oleh perguruan tinggi untuk kelulusan mahasiswa di perguruan tinggi tersebut.

Berbagai disiplin ilmu yang ada, menurut ilmu perpustakaan dapat dikelompokkan dalam beberapa kelaskelas bidang ilmu untuk memudahkan penyimpanan dan penemuan kembali informasi. Sistem UDC merupakan salah satu skema klasifikasi yang digunakan perpustakaan dalam mengelompokan bahan perpustakaan 
berdasarkan subyeknya yang dinyatakan dengan nomor kelas. Sistem klasifikasi pada UDC menganggap seluruh bidang ilmu pengetahuan sebagai suatu kesatuan dan dibagi menjadi sepuluh kelas, maka masing masing kelas dibagi menjadi bagian bagian logis, setiap subdivisi kemudian dibagi lagi dan seterusnya (Sulistyo-Basuki, 1991). Tabel utama garis besar berbagai disiplin ilmu pengetahuan diatur dalam 10 kelas dan diberi nomor 0 sampai 9. Mulai dari (0) Sain dan Pengetahuan; Organisasi; Ilmu Komputer; Ilmu Informasi; Dokumentasi; Kepustakawanan; Lembaga; dan Publikasi, (1) Filsafat; dan Psikologi. (2) Agama; Teologi. (3) Ilmu sosial, (4) Kosong, (5) Matematika dan Ilmu Pengetahuan Alam, (6) Ilmu Terapan; Kedokteran; Teknologi. (7) Seni; Olah Raga; Landscape (8) Kesusastraan; Linguistik; Bahasa; dan Literatur, (9) Geografi; Biografi; dan Sejarah (Consortium, 2019).

Bidang atau disiplin ilmu Matematika dan Ilmu Pengetahuan Alam yang termasuk (Matematika, Biologi, Kimia, Fisika, Geofisika dan Meteorologi, serta Biokimia) sendiri berada dalam kelompok atau nomor kelasifikasi (5). Namun untuk Ilmu Komputer mendapatkan nomor kelas (0) dan Ilmu Statistika mendapat nomor (3). Tiga kelompok besar tersebut kemudian dibagi lagi menjadi bidang yang lebih spesifik, sehingga bisa disebutkan bahwa makin khusus atau makin spesifik suatu subyek, maka semakin panjang notasinya karena banyak angka yang ditambahkan pada notasi dasarnya.

Penelitian dilakukan berdasarkan pengelompokkan bidang ilmu MIPA berdasarkan standar klasifikasi Universal Decimal Classification (UDC) yaitu kelompok (5) Matematika dan Ilmu Pengetahuan Alam, (0) Ilmu komputer, dan (3) Ilmu Statistika, serta dengan kombinasi bidang lain yang berkaitan. Bidang ilmu yang diteliti dianataranya adalah: 1). Statistika, 2). Geofisika dan Meteorologi, 3). Biologi, 4). Kimia, 5). Matematika, 6). Ilmu Komputer, 7). Fisika dan 8). Biokimia. Masing-masing bidang ilmu tersebut dibagi lagi dengan subyek lebih spesifik sesuai standar Universal Decimal Classification (UDC).

Manfaat penelitian bibliometrika menurut Pattah (2013) salah satunya adalah untuk analisis kurikulum dan untuk menilai kualitas hasil penelitian. Hal yang sama sebagaimana diungkapkan Marraro (2008) dalam (Pattah, 2013:48) bahwa bibliometrika dapat digunakan di semua aspek kuantitaif dan metode komunikasi ilmiah, penyimpanan, penyebarluasan, dan temu kembali informasi ilmiah. Objek kajian dalam bibliometrika sebagaimana diungkapkan Glazel (2009) dalam (Pattah, 2013:51) adalah berbagai jenis literatur ilmiah, seperti buku, monogaraf, laporan penelitian, tesis, disertasi, artikel dalam serial dan periodikal, dan dokumen primer lainnya.

Fakultas Matematika dan Ilmu Pengetahuan Alam (MIPA) adalah salah satu dari sembilan fakultas utama yang bernaung dan ada di bawah bendera IPB University dan memiliki 8(delapan) departemen, yaitu: Statistika, Geofisika dan Meteorologi, Biologi, Kimia, Matematika, Ilmu Komputer, Fisika, dan Departemen Biokimia. Semua mahasiswa Fakultas Matematika dan Ilmu Pengetahuan Alam yang telah berakhir masa belajar berkewajiban melakukan penelitian dan membuat laporan dalam bentuk karya tulis akademik (skripsi). Kegiatan tersebut dilakukan sebagai upaya kontribusi positif mahasiswa lulusan Fakultas Matematika dan Ilmu Pengetahuan Alam IPB University dalam meningkatkan ilmu pengetahuan dan pengembangan teknologi dengan berbagai topik penelitian di bidang matematika dan ilmu pengetahuan alam. Sejak dari tahun 1982 sampai tahun 2019 Fakultas Matematika dan Ilmu Pengetahuan Alam IPB University telah berkontribusi dan menghasilkan 12.073 judul skripsi yang 
tercatat dan ada di pangkalan data Perpustakaan IPB University. Sementara bila dihitung hanya lima tahun terakhir saja dari tahun 2015 sampai tahun 2019 tercatat dan ada di pangkalan data Perpustakaan IPB University sekitar 3.550 judul.

Penelitian tentang Pemetaan Informasi Sebaran Bidang Ilmu Pada Skripsi Fakultas Matematika dan Ilmu Pengetahuan Alam IPB University Lulusan Tahun 2015-2019 berdasarkan Standar Universal Decimal Classification (UDC) yang merupakan informasi penting sebaran topik penelitian, sebaran bidang ilmu berdasarkan Standar Universal Decimal Classification (UDC), dan peta jalan (road map) kata kunci bisa divisualisasikan, serta produktivitas dosen pembimbing perlu diteliti dengan menerapkan teori bibliometrika dengan asumsi bahwa konsep tersebut bisa diidentifikasikan dan dianalisis untuk berbagai kepentingan dan kebijakan.

Hasil penelitian mendeskripsikan secara statistik dan analisis, tentang sejauhmana konsep penelitian Pemetaan Informasi Sebaran Bidang Ilmu Pada Skripsi Fakultas Matematika dan Ilmu Pengetahuan Alam IPB University Lulusan Tahun 2015-2019 Berdasarkan Standar Universal Decimal Classification (UDC): Suatu Kajian Bibliometrika dapat dikatakan tetap masuk akal atau logik bila dipadu-padankan dengan data yang ada dan dianggap relevan untuk menjelaskan keterkaitan konsep penelitian dengan yang menjadi landasan maupun rujukan bagi penelitian yang akan dilakukan.

Penelitian yang dilakukan untuk mengukur 'Sejauhmana informasi sebaran jumlah topik penelitian, sebaran bidang ilmu berdasarkan Universal Decimal Classification (UDC), dan visualisasi peta jalan (road map) kata kunci, serta produktivitas dosen pembimbing pada skripsi Fakultas Matematika dan Ilmu Pengetahuan Alam IPB University lulusan Tahun 2015-2019?““.

\section{Metode Penelitian}

Penelitian ini merupakan suatu kajian bibliometrik dengan metode penelitian kuantitatif, bertujuan untuk mendeskripsikan pemetaan informasi sebaran bidang ilmu pada skripsi Fakultas Matematika dan Ilmu Pengetahuan Alam di Institut Pertanian Bogor. Pengolahan Data Penelitian. Obyek penelitian ini adalah data skripsi Fakultas Matematika dan Ilmu Pengetahuan Alam pada pangkalan data Perpustakaan IPB University. Data diolah menggunakan Program M.S. Excel dan dikelompokkan berdasarkan standar Universal Decimal Classification. Data kata kunci dibuat File RIS (RIS File) dan dianalisis menggunakan Program VosViewerVisualizing Scientific Landscapes 1.6.1.5 yang dikembangkan oleh Nees Jan Van Eck dan Ludo Waltman.

Proses operasionalisasi penelitian ini dilakukan melalui beberapa tahapan, diawali dengan menentukan dan mengumpulankan data dari populasi obyek penelitian berupa daftar keseluruhan dari skripsi Mahasiswa Fakultas Matematika dan Ilmu Pengetahuan Alam. Daftar skripsi tersebut memuat sekitar 12.073 judul skripsi yang tercatat dan ada di pangkalan data Perpustakaan IPB University. Sementara yang menjadi sampel dalam penelitian ini ditentukan hanya lima tahun terakhir saja, dari tahun 2015 sampai tahun 2019 berjumlah sekitar 3.550 judul. Daftar skripsi yang menjadi sampel dalam penelitian ini kemudian dibuat dan disajikan dalam tipe File Excel. Tabel tersebut berisikan informasi: Nomor Panggil yang berisikan terdiri atas (fakultas, departemen, tahun, dan nomor urut); Pengarang (nama mahasiswa); Judul Skripsi; dan Nama Pembimbing (pembimbing kesatu, pembimbing kedua, dan pembimbing ketiga). 
Tabel utama instrumen penelitian dijadikan acuan bagi tabel data lainnya, kemudian dilakukan proses tabulasi data dengan bantuan Program M.S. Excel berdasarkan kelompok departemen yang ada di Fakultas Matematika dan Ilmu Pengetahuan Alam yaitu, Departemen; Statistika (STK), Geofisika \& Meteorologi (GFM), Biologi (BIO), Kimia (KIM), Matematika (MTK), Ilmu Komputer (KOM), Fisika (FIS), dan Departemen Biokimia (BIOKIM). Kemudiaan data yang telah dikelompokkan dalam bentuk tabel pada Program M.S. Excel tersebut diolah sedemikian rupa sehingga menghasilkan beberapa informasi penting diantaranya adalah: Sebaran Jumlah topik penelitian; Sebaran Jumlah topik penelitian berdasarkan departemen; Sebaran bidang ilmu berdasarkan Universal Decimal Classification (UDC); dan Visualisasi sebaran kata kunci, serta Sebaran bimbingan skripsi oleh pembimbing kesatu; Sebaran jumlah bimbingan skripsi oleh pembimbing kedua; Sebaran jumlah bimbingan skripsi oleh pembimbing ketiga, pada skripsi FMIPA IPB University lulusan Tahun 2015 sampai dengan Tahun 2019.

\section{Hasil Penelitian}

\section{Topik Penelitian}

Skripsi merupakan karya tulis akademik mahasiswa program strata satu yang wajib dibuat oleh mahasiswa tingkat akhir dengan topik penelitian dan metode tertentu sesuai disiplin ilmu yang ditempuh di bawah bimbingan dosen pembimbing yang ahli di bidangnya. Fakultas Matematika dan Ilmu Pengetahuan Alam, selanjutnya disingkat FMIPA merupakan satu dari sembilan fakultas utama yang bernaung dan ada di bawah bendera IPB University dan memiliki 8(delapan) departemen, yaitu: Statistika, Geofisika dan Meteorologi, Biologi, Kimia, Matematika, Ilmu Komputer, Fisika, dan Departemen Biokimia. Setiap departemen yang ada di FMIPA IPB University tersebut pada setiap tahun ajaran menghasilkan banyak skripsi sebagai tugas akhir yang wajib diselesaikan oleh mahasiswa.

Penelitian ini menginformasikan bahwa jumlah topik penelitian pada skripsi mahasiswa FMIPA IPB University selama kurun waktu lima tahun terakhir yaitu dari Tahun 2015 sampai dengan Tahun 2019 berjumlah sekitar 3.550 judul topik penelitian.

Tabel 1 Sebaran Jumlah Topik Skripsi FMIPA Berdasarkan Tahun Lulusan Tahun 2015 sampai dengan Tahun 2019

\begin{tabular}{clcccccc}
\hline \multirow{2}{*}{ No. } & \multicolumn{2}{c}{ Departemen } & \multicolumn{3}{c}{ Tahun Lulusan } & \multirow{2}{*}{ Jumlah } \\
\cline { 3 - 6 } & & $\mathbf{2 0 1 5}$ & $\mathbf{2 0 1 6}$ & $\mathbf{2 0 1 7}$ & $\mathbf{2 0 1 8}$ & $\mathbf{2 0 1 9}$ & \\
\hline 1 & Komputer (KOM) & 141 & 145 & 139 & 152 & 142 & $\mathbf{7 1 9}$ \\
2 & Kimia (KIM) & 98 & 102 & 110 & 105 & 113 & $\mathbf{5 2 8}$ \\
3 & Biologi (BIO) & 107 & 92 & 105 & 109 & 94 & $\mathbf{5 0 7}$ \\
4 & Biokimia (BIK) & 80 & 77 & 78 & 87 & 86 & $\mathbf{4 0 8}$ \\
5 & Statistika (STK) & 77 & 89 & 67 & 79 & 75 & $\mathbf{3 8 7}$ \\
6 & Geofisika dan Meteorologi (GFM) & 60 & 89 & 69 & 76 & 64 & $\mathbf{3 5 8}$ \\
7 & Matematika (MAT) & 76 & 69 & 59 & 58 & 70 & $\mathbf{3 3 2}$ \\
8 & Fisika (FIS) & 59 & 67 & 57 & 71 & 57 & $\mathbf{3 1 1}$ \\
\hline Jumlahn & $\mathbf{6 9 8}$ & $\mathbf{7 3 0}$ & $\mathbf{6 8 4}$ & $\mathbf{7 3 7}$ & $\mathbf{7 0 1}$ & $\mathbf{3 . 5 5 0}$ \\
Persentase (\%) & $19,66 \%$ & $20,56 \%$ & $19,27 \%$ & $20,76 \%$ & $19,75 \%$ & $100 \%$ \\
\hline
\end{tabular}

Berdasarkan informasi sebaran jumlah topik penelitian pada Tabel 1 dapat diketahui sebaran jumlah hasil penelitian skripsi Fakultas Matematika dan Ilmu
Pengetahuan Alam (FMIPA) IPB University lulusan tahun 2015 sampai dengan 2019. 
Tabel 2 Sebaran Jumlah Skripsi FMIPA Berdasarkan Departemen Lulusan Tahun 2015 sampai dengan Tahun 2019

\begin{tabular}{clcc}
\hline No. & \multicolumn{1}{c}{ Nama Departemen } & Volume & $\begin{array}{c}\text { Persentase } \\
\mathbf{( \% )}\end{array}$ \\
\hline 1 & Komputer (KOM) & 719 & $20,25 \%$ \\
2 & Kimia (KIM) & 528 & $14,87 \%$ \\
3 & Biologi (BIO) & 507 & $14,28 \%$ \\
4 & Biokimia (BIK) & 408 & $11,49 \%$ \\
5 & Statistika (STK) & 387 & $10,90 \%$ \\
6 & Geofisika dan Meteorologi (GFM) & 358 & $10,08 \%$ \\
7 & Matematika (MTK) & 332 & $9,35 \%$ \\
8 & Fisika (FIS) & 311 & $8,76 \%$ \\
\hline
\end{tabular}

Tabel 2. menunjukan sebaran jumlah penelitian skripsi Fakultas Matematika dan Ilmu Pengetahuan Alam IPB University lulusan tahun 2015 sampai 2019 berdasarkan volume dan persentase dari masing-masing departemen. Penelitian yang dilakukan oleh Departemen Komputer (KOM) yaitu sebanyak 719 penelitian (20,25\%), diikuti Departemen Kimia (KIM) sebagai terbanyak kedua yaitu 528 penelitian (14,87\%). Kemudian disusul Departemen Biologi (BIO) sebagai terbanyak ketiga berjumlah 507 penelitian (14,28\%), Selanjutnya Departemen Biokimia (BIK) yang telah melakukan sebanyak 408 penelitan (11,49\%), sedangkan Departemen Statistika (STK) sebanyak 387 penelitian (10,90\%), dan Departemen Geofisika dan Meteorologi (GFM) sebanyak
358 penelitian $(10,08 \%)$, serta pada Departemen Matematika (MTK) sebanyak 332 penelitian $(9,35 \%)$. Namun jumlah penelitian paling sedikit oleh Departemen Fisika (FIS) sebanyak 311 penelitian $(8,76 \%)$ saja.

\section{Bidang Ilmu Berdasarkan UDC}

Pengelompokan penelitian pada skripsi FMIPA IPB University lulusan Tahun 2015 sampai dengan Tahun 2019 berdasarkan UDC berada pada empat wilayah kelompok bidang ilmu yaitu: kelompok umum termasuk dalam kategori kelompok Sains dan pengetahuan (kelas 000); kelompok ilmu pengetahuan sosial (kelas 300); dan kelompok ilmu-ilmu murni dan ilmu pengetahuan alam (kelas 500).

Tabel 3 Sebaran Jumlah Bidang Ilmu Skripsi FMIPA Berdasarkan UDC Lulusan Tahun 2015 sampai dengan Tahun 2019

\begin{tabular}{lllcc}
\hline \multicolumn{1}{c}{ Klas. } & \multicolumn{1}{c}{ Bidang Ilmu } & Volume & $\begin{array}{c}\text { Persentase } \\
(\mathbf{\%})\end{array}$ \\
\hline $\mathbf{0 0 4}$ & $:$ & Ilmu dan Tek. Komputer. Komputasi. Pemrosesan data & $20,25 \%$ \\
$\mathbf{5 7 0}$ & $:$ & Ilmu-Ilmu Hayati & 719 & $17,77 \%$ \\
$\mathbf{5 4 0}$ & $:$ & Kimia, Kristalografi, Mineralogi & 631 & $16,08 \%$ \\
$\mathbf{5 0 0}$ & $:$ & Matematika & 571 & $11,15 \%$ \\
$\mathbf{3 1 1}$ & $:$ & Statistika Sebagai Suatu Ilmu. Teori Statistik & 396 & $10,90 \%$ \\
$\mathbf{5 3 0}$ & $:$ & Fisika & 387 & $9,44 \%$ \\
$\mathbf{5 5 0}$ & $:$ & Ilmu Bumi dan Geologi & 335 & $6,03 \%$ \\
$\mathbf{5 8 0}$ & $:$ & Botani & 214 & $5,15 \%$ \\
$\mathbf{5 0 2}$ & $:$ & Ilmu Lingkungan & 183 & $2,00 \%$ \\
$\mathbf{5 9 0}$ & $:$ & Zoologi & 71 & $1,21 \%$ \\
\hline
\end{tabular}

Pada tabel 3 dapat dilihan sebaran Informasi bidang ilmu berdasarkan UDC pada skripsi Fakultas Matematika dan Ilmu Pengetahuan Alam IPB University lulusan Tahun 2015 sampai dengan Tahun 2019. 
Tabel 4 Sebaran Sub Bidang Ilmu Pada Skripsi FMIPA Berdasarkan UDC

Lulusan Tahun 2015 sampai dengan Tahun 2019

\begin{tabular}{|c|c|c|c|c|}
\hline Klas. & & Bidang Ilmu & Volume & $\begin{array}{c}\text { Persentase } \\
(\%)\end{array}$ \\
\hline 519 & $:$ & Analisis kombinatorial. Teori graf & 298 & $8,39 \%$ \\
\hline 004.4 & : & Perangkat Lunak & 267 & $7,52 \%$ \\
\hline 579 & : & Mikrobiologi & 250 & $7,04 \%$ \\
\hline 547 & : & Kimia organik & 188 & $5,30 \%$ \\
\hline 551 & $:$ & $\begin{array}{l}\text { Geologi umum. Meteorologi. Klimatologi. Geologi historis. } \\
\text { Stratigrafi. Palaeografi }\end{array}$ & 160 & $4,51 \%$ \\
\hline $53-01 / 09$ & $:$ & Fisika dasar & 155 & $4,37 \%$ \\
\hline 542 & : & Laboratorium praktis kimia. Kimia preparat dan eksperimen & 154 & $4,34 \%$ \\
\hline 004 & : & Ilmu dan teknologi komputer. Komputasi. Pemrosesan data & 154 & $4,34 \%$ \\
\hline 311 & : & Statistika sebagai suatu ilmu. Teori statistik & 133 & $3,75 \%$ \\
\hline 577 & : & $\begin{array}{l}\text { Dasar alami kehidupan. Biokimia. Biologi molekuler. } \\
\text { Biofisika }\end{array}$ & 116 & $3,27 \%$ \\
\hline $57.01 / .8$ & : & $\begin{array}{l}\text { Subdivisi tambahan khusus untuk aspek teoretis, } \\
\text { karakteristik, faktor dsb. pada biologi }\end{array}$ & 105 & $2,96 \%$ \\
\hline 582 & : & Botani sistematik & 105 & $2,96 \%$ \\
\hline 004.9 & : & Teknik berbasis komputer berorientasi aplikasi & 105 & $2,96 \%$ \\
\hline 311.2 & : & Teknik penelitian. Persiapan. Tabulasi & 96 & $2,70 \%$ \\
\hline 004.7 & : & Komunikasi komputer. Jaringan komputer & 91 & $2,56 \%$ \\
\hline 311.3 & : & Organisasi/Susunan statistik umum. Statistik resmi & 90 & $2,54 \%$ \\
\hline 574 & : & Ekologi dan biodiversitas umum & 84 & $2,37 \%$ \\
\hline 581 & : & Botani umum & 78 & $2,20 \%$ \\
\hline $548 / 549$ & : & Ilmu mineralogi. Kristalografi. Minerologi & 77 & $2,17 \%$ \\
\hline 517 & : & Analisis matematika & 70 & $1,97 \%$ \\
\hline 311.4 & : & Statistik khusus (swasta) & 68 & $1,92 \%$ \\
\hline 576 & : & Biologi sel dan subsel. Sitologi & 60 & $1,69 \%$ \\
\hline $531 / 534$ & : & Mekanika & 55 & $1,55 \%$ \\
\hline 556 & : & Hidrosfer. Air pada umumnya. Hidrologi & 54 & $1,52 \%$ \\
\hline 544 & $:$ & Kimia fisik & 54 & $1,52 \%$ \\
\hline 543 & $:$ & Kimia analitis & 43 & $1,21 \%$ \\
\hline 502 & : & Lingkungan dan perlindungannya & 43 & $1,21 \%$ \\
\hline $54.01 / .08$ & : & $\begin{array}{l}\text { Subdivisi tambahan khusus untuk komposisi, produksi, } \\
\text { persiapan dan analisis }\end{array}$ & 42 & $1,18 \%$ \\
\hline 536 & $:$ & Panas. Termodinamika. Fisika statistik & 40 & $1,13 \%$ \\
\hline 004.6 & $:$ & Data & 37 & $1,04 \%$ \\
\hline 535 & $:$ & Optik & 33 & $0,93 \%$ \\
\hline 004.2 & $:$ & Arsitektur komputer & 30 & $0,85 \%$ \\
\hline 539 & $:$ & Sifat fisika zat & 29 & $0,82 \%$ \\
\hline 504 & $:$ & Ancaman terhadap lingkungan & 28 & $0,79 \%$ \\
\hline 004.8 & : & Kecerdasan buatan & 26 & $0,73 \%$ \\
\hline 537 & $:$ & Kelistrikan. Magnetisme. Elektromagnetisme & 23 & $0,65 \%$ \\
\hline 595.7 & : & Heksapoda. Insekta (serangga) & 19 & $0,54 \%$ \\
\hline 575 & $:$ & Genetika umum. Sitogenetika umum & 16 & $0,45 \%$ \\
\hline 510 & : & Pertimbangan dasar dan umum matematika & 15 & $0,42 \%$ \\
\hline 599 & : & Mamalia (Mamal, Binatang menyusui) & 12 & $0,34 \%$ \\
\hline $54-1 /-4$ & : & Subdivisi tambahan khusus untuk keadaan zat, kimia & 10 & $0,28 \%$ \\
\hline 004.5 & $:$ & $\begin{array}{l}\text { Interaksi Orang-komputer. Antarmuka Orang-mesin. } \\
\text { Antarmuka pengguna. Lingkungan pengguna }\end{array}$ & 9 & $0,25 \%$ \\
\hline 511 & $:$ & Teori bilangan & 6 & $0,17 \%$ \\
\hline 594 & : & Moluska. Briozoa. Brakiopoda & 5 & $0,14 \%$ \\
\hline 514 & : & Geometri & 4 & $0,11 \%$ \\
\hline 512 & $:$ & Aljabar & 3 & $0,08 \%$ \\
\hline 546 & $:$ & Kimia anorganik & 3 & $0,08 \%$ \\
\hline 591 & : & Zoologi umum & 3 & $0,08 \%$ \\
\hline 595 & : & Articulata & 3 & $0,08 \%$ \\
\hline 598.1 & : & Reptilia (Reptil) & 1 & $0,03 \%$ \\
\hline
\end{tabular}

\section{Visualisasi Peta Jalan}

Penelitian ini melaporkan proses visualisasi peta jalan (road map) data yang telah diolah dan dianalisis dengan bantuan Program VosViewer - Visualizing Scientific Landscapes Versi 1.6.1.5 dikembangkan
Nees Jan Van Eck dan Ludo Waltman. Namun sebelum melakukan proses kegiatan analisis tersebut, perlu dilakukan pengeditan data sesuai keperluan dan merubah tabel kata kunci dalam format Excel tersebut 
menjadi data format RIS File. Setelah data tersaji dalam format RIS File kemudian dilakukan kegiatan proses analisis data mengikuti petunjuk.

Kegiatan analisis data yang dilakukan tersebut meliputi kegiatan analisis: visualisasi jaringan (Network Visualization), visualisasi hamparan (Overlay Visualization), dan visualisasi kepadatan (Density Visualization) terhadap kata kunci yang telah ditentukan dalam format RIS File. Program VosViewer Versi 1.6.1.5 saat dioperasikan dalam membuat pemetaan (creat map) pada penelitian ini memilih tipe kata kunci terjadi bersama (keyword co-occurrence) dan memilih sumber data (Choose data source) yang membaca data dari file manajer referensi (Read data from reference manager files) dan mendukung tipe File RIS, serta menentukan pilihan jenis metode penghitungan penuh (Full counting methode), dan memilih ambang batas (Choose threshold) pada jumlah kemunculan kata minimum (Minimum number occurrences of word) dan ditentukan 5 kali dari keseluruhan 11.095 butir (item) kata kunci, serta 699 butir (item) diantaranya memenuhi ambang batas (meet the threshold). Kemudian setelah melakukan verifikasi yang dipilih (verify selected keywords) 683 butir (item) kata kunci, sehingga setelah menjalankan algoritme tata letak (running layout algoritm), maka Program VosViewer Versi 1.6.1.5 menampilkan hasil 683 butir (item) kata kunci yang tersebar pada 12 gugus (cluster). Informasi sebaran jumlah butir kata kunci berdasarkan hasil analisis Vosviewer bisa dilihat pada Tabel 9. berikutnya.

Tabel 5 Sebaran Jumlah Butir Kata Kunci Skripsi FMIPA Hasil Analisis Vosviewer Lulusan Tahun 2015 sampai dengan Tahun 2019

\begin{tabular}{ccc}
\hline $\begin{array}{c}\text { GUGUS } \\
\text { (Cluster) }\end{array}$ & $\begin{array}{c}\text { KATA KUNCI } \\
(\text { Item })\end{array}$ & $\begin{array}{c}\text { PERSENTASE } \\
\mathbf{( \% )})\end{array}$ \\
\hline 1 & 124 & $18,16 \%$ \\
2 & 91 & $13,32 \%$ \\
3 & 77 & $11,27 \%$ \\
4 & 72 & $10,54 \%$ \\
5 & 58 & $8,49 \%$ \\
6 & 58 & $8,49 \%$ \\
7 & 58 & $8,49 \%$ \\
8 & 54 & $7,91 \%$ \\
9 & 42 & $6,15 \%$ \\
10 & 27 & $3,95 \%$ \\
11 & 14 & $2,05 \%$ \\
12 & 8 & $1,17 \%$ \\
\hline JUMLAH & $\mathbf{6 8 3}$ & $\mathbf{1 0 0 , 0 0 \%}$ \\
\hline
\end{tabular}

Tabel 5. menunjukan urutan 12 gugus (cluster) sebaran jumlah kata kunci dari urutan terbanyak hingga paling sedikit. maka yang termasuk gugus (cluster): pertama 124 butir kata kunci $(18,16 \%)$; kedua 91 butir kata kunci $(13,32 \%)$; dan ketiga 77 butir kata kunci $(11,27 \%)$; keempat 72 butir kata kunci (10,54\%); dan kelima, keenam juga ketujuh masing-masing sama 58 butir kata kunci $(8,49 \%)$; sedangkan kedelapan 54 butir kata kunci $(7,91 \%)$; kesembilan sebanyak 42 butir kata kunci (6,15\%); dan kesepuluh sebanyak 27 butir kata kunci (3,95\%); dan yang terakhir kesebelas dan keduabelas berjumlah masing-masing 14 butir kata kunci $(2,05 \%)$ dan 8 butir kata kunci $(1,17 \%)$.

\subsection{Visualisasi Jaringan}

Penelitian ini telah berhasil menampilkan informasi hasil analisis dari Program VosViewer Versi 1.6.1.5 yang pernah dilakukan berupa Visualisasi jaringan, kata kunci pada Skripsi Fakultas Matematika dan Ilmu Pengetahuan Alam IPB University lulusan Tahun 2015 sampai dengan Tahun 2019, yang bisa 
dilihat pada Gambar 1. sebagaimana

berikut.

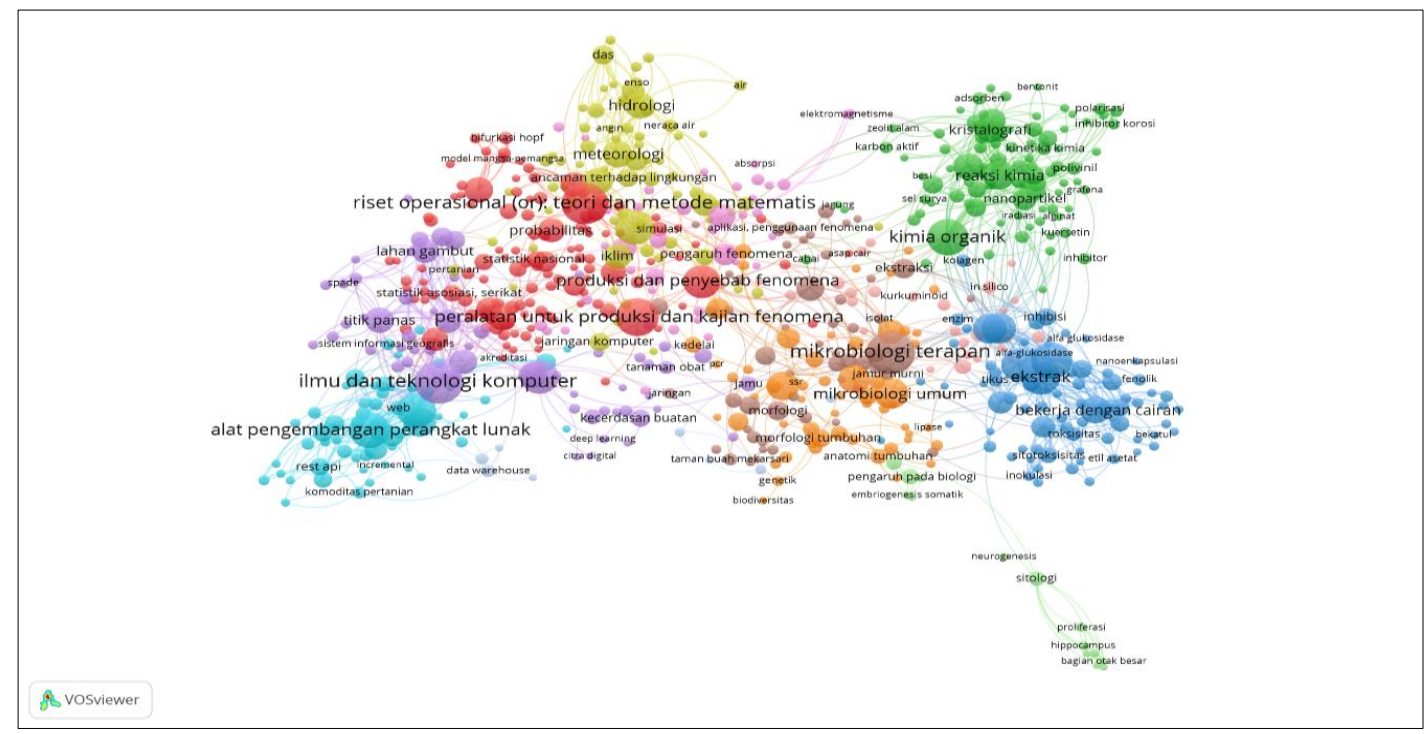

Gambar 1 Visualisasi Jaringan Kata Kunci

Gambar 1. Mengilustrasikan penelitian ini memberikan informasi visualisasi jaringan kata kunci hasil analisis Program VosViewer Versi 1.6.1.5 dimana terdapat beberapa gugus (cluster) kata kunci yang saling bertautan antara satu kata kunci dengan kata kunci lain, dan terlihat jelas berukuran lebih besar dari kata kunci lain disekitarnya disertai bulatan yang cederung besar dan berwarna menggambarkan masing-masing gugus (cluster). Visualisasi tersebut menandakan adanya kecenderungan (trend) tautan topik penelitian pada kata kunci tersebut pernah terjadi banyak penelitian, karena mungkin juga pernah banyak yang berminat menelitinya.

Penelitian ini melaporkan telah menemukan informasi sebaran 12 gugus (cluster) kata kunci dengan kecenderungan (trend) tautan topik penelitian pada skripsi Fakultas Matematika dan Ilmu Pengetahuan Alam IPB University lulusan Tahun 2015 sampai dengan Tahun 2019. Informasi sebaran kecenderungan (trend) tautan topik penelitian tersebut bisa dilihat pada Tabel 5 berikut.

Tabel 6 Sebaran Kecenderungan (trend) Tautan Topik Penelitian Skripsi FMIPA Lulusan Tahun 2015 sampai dengan Tahun 2019

\begin{tabular}{llccc}
\hline \multicolumn{1}{c}{ Kelas } & \multicolumn{1}{c}{ Kata kunci } & $\begin{array}{c}\text { Gugus } \\
\text { (Cluster) }\end{array}$ & $\begin{array}{c}\text { Kejadian } \\
\text { (Occurance) }\end{array}$ & $\begin{array}{c}\text { Total } \\
\text { Tautan } \\
\text { Jaringan }\end{array}$ \\
\hline $\mathbf{0 0 4}$ & Ilmu dan teknologi komputer & 5 & 153 & 397 \\
$\mathbf{5 7 9 . 4}$ & Mikrobiologi terapan & 8 & 152 & 237 \\
$\mathbf{5 1 9 . 8}$ & Riset operasi (OR): Metode dan matematis & 1 & 139 & 207 \\
$\mathbf{5 4 7}$ & Kimia organik & 2 & 111 & 240 \\
$\mathbf{0 0 4 . 4}$ & Alat pengembangan perangkat lunak & 6 & 111 & 297 \\
$\mathbf{5 7 7}$ & Dasar alami kehidupan & 3 & 110 & 314 \\
$\mathbf{5 5 1 . 5 8}$ & Klimatologi & 4 & 98 & 229 \\
$\mathbf{5 7 9 . 2}$ & Mikro biologi umum & 7 & 77 & 117 \\
$\mathbf{5 4 . 0 8}$ & Metode & 9 & 48 & 116 \\
$\mathbf{5 4 2 . 9}$ & Sitologi & 11 & 20 & 60 \\
$\mathbf{5 4 9 . 7}$ & Senyawa lain - [asamoksida] & 10 & 18 & 57 \\
$\mathbf{0 0 4 . 6 5}$ & Data warehouse - [gudang data] & 12 & 13 & 43 \\
\hline
\end{tabular}

Tabel 6. Mengilustrasikan bahwa sebaran kecenderungan (trend) tautan topik penelitian pada skripsi Fakultas Matematika dan Ilmu Pengetahuan Alam
IPB University lulusan tahun 2015 sampai dengan tahun 2019 adalah pada kata kunci: Ilmu dan teknologi komputer (004) ada pada gugus 5 dengan 153 kejadian dan 
397 tautan; Mikrobiologi terapan (579.4) ada pada gugus 8 dengan 152 kejadian dan 237 tautan; Riset operasi (OR): Metode dan matematis (579.4) ada pada gugus 1 dengan 139 kejadian dan 207 tautan; Kimia organik (547) ada pada gugus 2 dengan 111 kejadian dan 240 tautan; Alat pengembangan perangkat lunak (004.4) ada pada gugus 6 dengan 111 kejadian dan 297 tautan; Dasar alami kehidupan (577) ada pada gugus 3 dengan 110 kejadian dan 314 tautan; Klimatologi (551.58) ada pada gugus 4 dengan 98 kejadian dan 229 tautan; Mikro biologi umum (579.2) ada pada gugus 7 dengan 77 kejadian dan 117 tautan; Metode (54.08) ada pada gugus 9 dengan 48 kejadian dan 116 tautan; Sitologi (542.9) ada pada gugus 11 dengan 20 kejadian dan 60 tautan; Senyawa lain [asamoksida] (549.7) ada pada gugus 10 dengan 18 kejadian dan 57 tautan; Data warehouse [gudang data] (004.65) ada pada gugus 12 dengan 13 kejadian dan 43 tautan.

Informasi sebaran kecenderungan (trend) topik penelitian paling banyak kejadian muncul pada skripsi Fakultas Matematika Ilmu Pengetahuan Alam IPB University lulusan tahun 2015 sampai dengan tahun 2019 tiga diantaranya adalah sebagaimana bisa dilihat pada visualisasi Gambar 2, 3, dan 4 berikut ini.

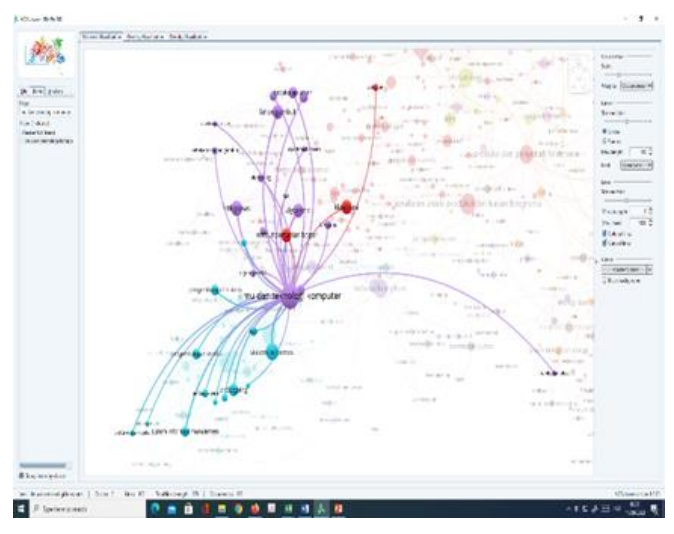

Gambar 2 Visualisasi Jaringan

"Ilmu dan teknologi komputer"

(Cluster 5:153 item : 397 total link strength)

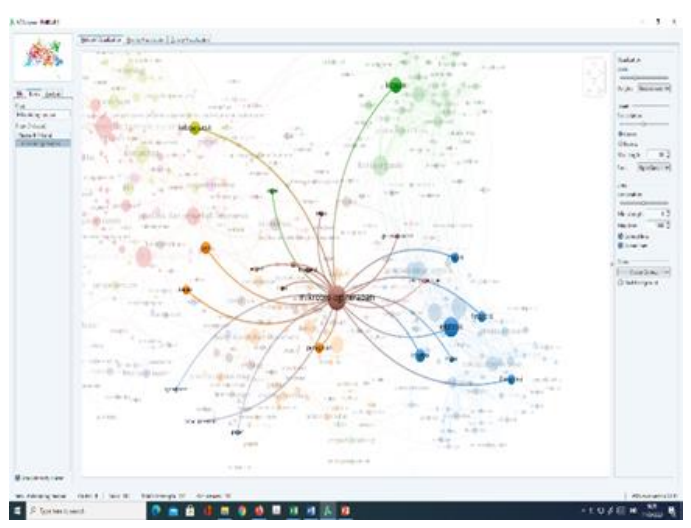

Gambar 3. Visualisasi Jaringan "Mikrobiologi terapan"

(Cluster 8:152 item : 237 total link strength)

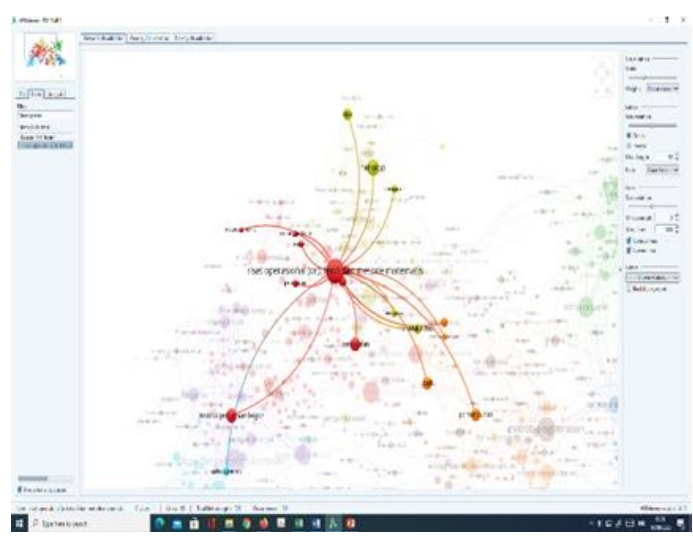

Gambar. 4. Visualisasi Jaringan

"Riset operasional: Teori dan metode matemtis"

(Cluster 1:139 item : 207 total link strength)

\subsection{Visualisasi Hamparan}

Penelitian ini telah berhasil menampilkan informasi hasil analisis dari Program VosViewer Versi 1.6.1.5 yang pernah dilakukan berupa Visualisasi hamparan kata kunci pada skripsi Fakultas Matematika dan Ilmu Pengetahuan Alam IPB University lulusan Tahun 2015 sampai dengan Tahun 2019, yang bisa dilihat pada ilustrasi Gambar 5. berikut. 


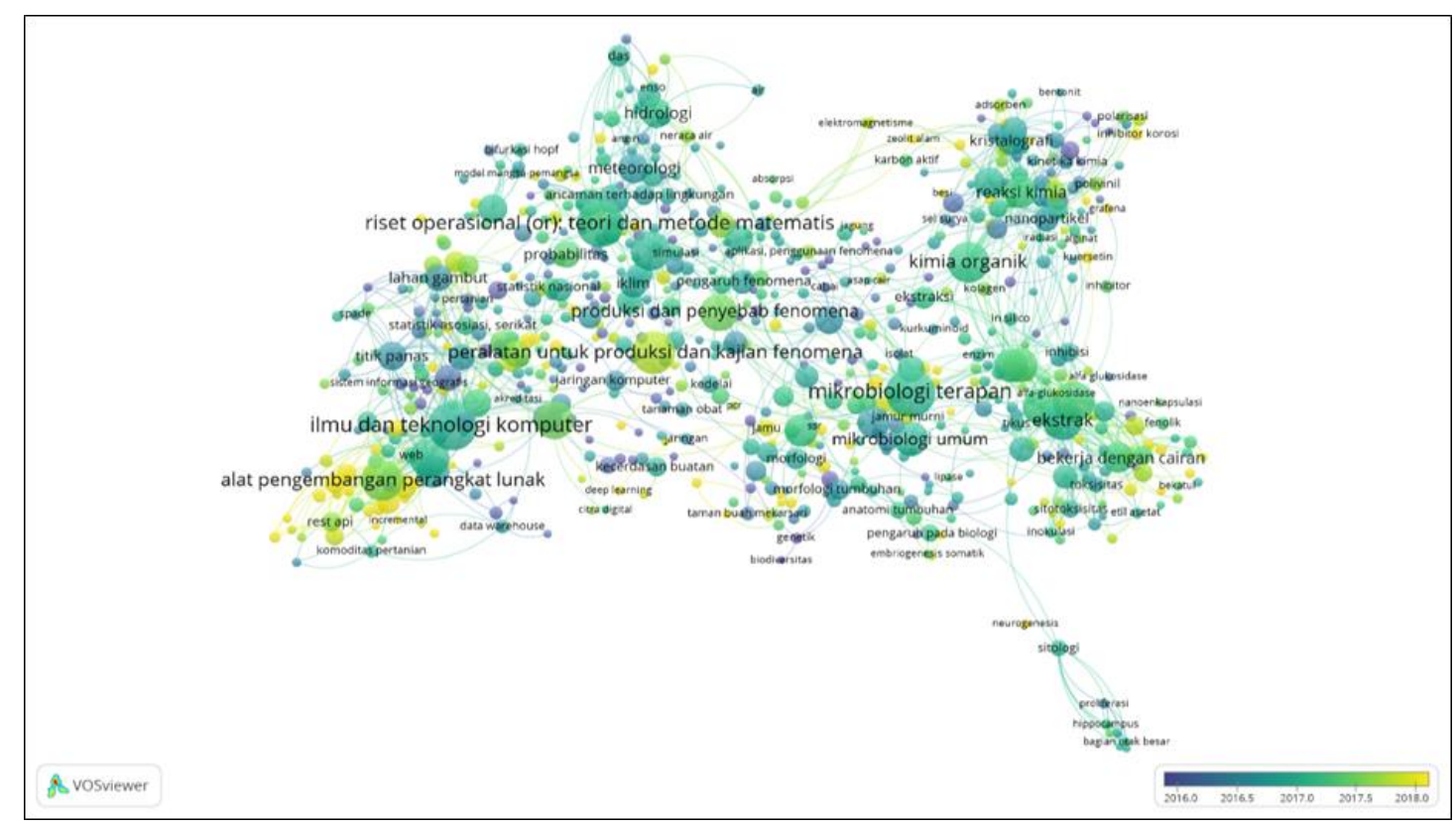

Gambar 5. Visualisasi Hamparan Kata Kunci

Gambar 5. Mengilustrasikan penelitian ini memberikan informasi visualisasi hamparan kata kunci hasil analisis Program VosViewer Versi 1.6.1.5 dimana terdapat 12 gugus (cluster) kata kunci yang saling berkaitan antara satu kata kunci dengan kata kunci lain, dan terlihat jelas berukuran lebih besar dari kata kunci lain disekitarnya, berbentuk bulatan besar dan berwarna. Visualisasi tersebut sebenarnya menandakan ada kecenderungan (trend) peminatan topik penelitian terhadap kata kunci tersebut pada tahun-tahun tertentu sebagaimana terlihat dari informasi yang ada di sudut kanan bawah pada Gambar 8. Visualisasi Hamparan Kata Kunci.

Penelitian ini menemukan sekurangnya 12 gugus (cluster) kata kunci pada skripsi Fakultas Matematika dan Ilmu Pengetahuan Alam IPB

University lulusan Tahun 2015 sampai dengan Tahun 2019 dengan kecenderungan (trend) tahun penelitian untuk kata kunci tersebut pernah dilakukan sekitar Tahun 2016 sampai dengan Tahun 2018. Informasi sebaran kecenderungan (trend) tahun penelitian bisa dilihat pada Tabel 6 . sebagaimana berikut.

Tabel 6 Sebaran Kecenderungan (trend) Tahun Penelitian Skripsi FMIPA Lulusan Tahun 2015 sampai dengan Tahun 2019

\begin{tabular}{|c|c|c|c|c|}
\hline Kelas & Kata kunci & Gugus (Cluster) & $\begin{array}{l}\text { Tautan } \\
\text { Jaringan }\end{array}$ & $\begin{array}{l}\text { Tahun } \\
\text { Penelitian }\end{array}$ \\
\hline 004 & Ilmu dan teknologi komputer & 5 & 397 & 2017 \\
\hline 579.4 & Mikrobiologi terapan & 8 & 237 & 2017 \\
\hline 519.8 & $\begin{array}{l}\text { Riset operasi (OR): Metode dan } \\
\text { matematis }\end{array}$ & 1 & 207 & 2017 \\
\hline 547 & Kimia organik & 2 & 240 & 2017 \\
\hline 004.4 & Alat pengembangan perangkat lunak & 6 & 297 & 2018 \\
\hline 577 & Dasar alami kehidupan & 3 & 314 & 2017 \\
\hline 551.58 & Klimatologi & 4 & 229 & 2017 \\
\hline 579.2 & Mikro biologi umum & 7 & 117 & 2017 \\
\hline 54.08 & Metode & 9 & 116 & 2017 \\
\hline 542.9 & Sitologi & 11 & 60 & 2017 \\
\hline 549.7 & Senyawa lain - [asamoksida] & 10 & 57 & 2016 \\
\hline 004.65 & Data warehouse - [gudang data] & 12 & 43 & 2017 \\
\hline
\end{tabular}


Tabel 6. Mengilustrasikan bahwa sebaran kecenderungan (trend) tahun penelitian pada skripsi Fakultas Matematika dan Ilmu Pengetahuan Alam yang bisa dijelaskan sebagaimana berikut: Ilmu dan teknologi komputer (004) ada pada gugus 5 dengan 397 tautan pernah diteliti tahun 2017; Mikrobiologi terapan (579.4) ada pada gugus 8 dengan 237 tautan pernah diteliti tahun 2017; Riset operasi (OR): Metode dan matematis (579.4) ada pada gugus 1 dengan 207 tautan pernah diteliti tahun 2017; Kimia organik (547) ada pada gugus 2 dengan 240 tautan pernah diteliti tahun 2017; Alat pengembangan perangkat lunak (004.4) ada pada gugus 6 dengan 297 tautan pernah diteliti tahun 2018; Dasar alami kehidupan (577) ada pada gugus 3 dengan 314 tautan pernah diteliti tahun 2017; Klimatologi (551.58) ada pada gugus 4 dengan 229 tautan pernah diteliti tahun 2017; Mikro biologi umum (579.2) ada pada gugus 7 dengan 117 tautan pernah diteliti tahun 2017; Metode (54.08) ada pada gugus 9 dengan 116 tautan pernah diteliti tahun 2017; Sitologi (542.9) ada pada gugus 11 dengan 60 tautan pernah diteliti tahun 2017; Senyawa lain [asamoksida] (549.7) ada pada gugus 10 dengan 57 tautan pernah diteliti tahun 2016 ;

Data warehouse [gudang data] (004.65) ada pada gugus 12 dengan 43 tautan pernah diteliti tahun 2017.

\subsection{Visualisasi Kepadatan}

Penelitian ini telah berhasil menampilkan informasi hasil analisis dari Program VosViewer Versi 1.6.1.5 yang pernah dilakukan berupa Visualisasi kepadatan kunci pada skripsi Fakultas Matematika dan Ilmu Pengetahuan Alam IPB University lulusan Tahun 2015 sampai dengan Tahun 2019, yang bisa dilihat pada ilustrasi Gambar 9. berikut.

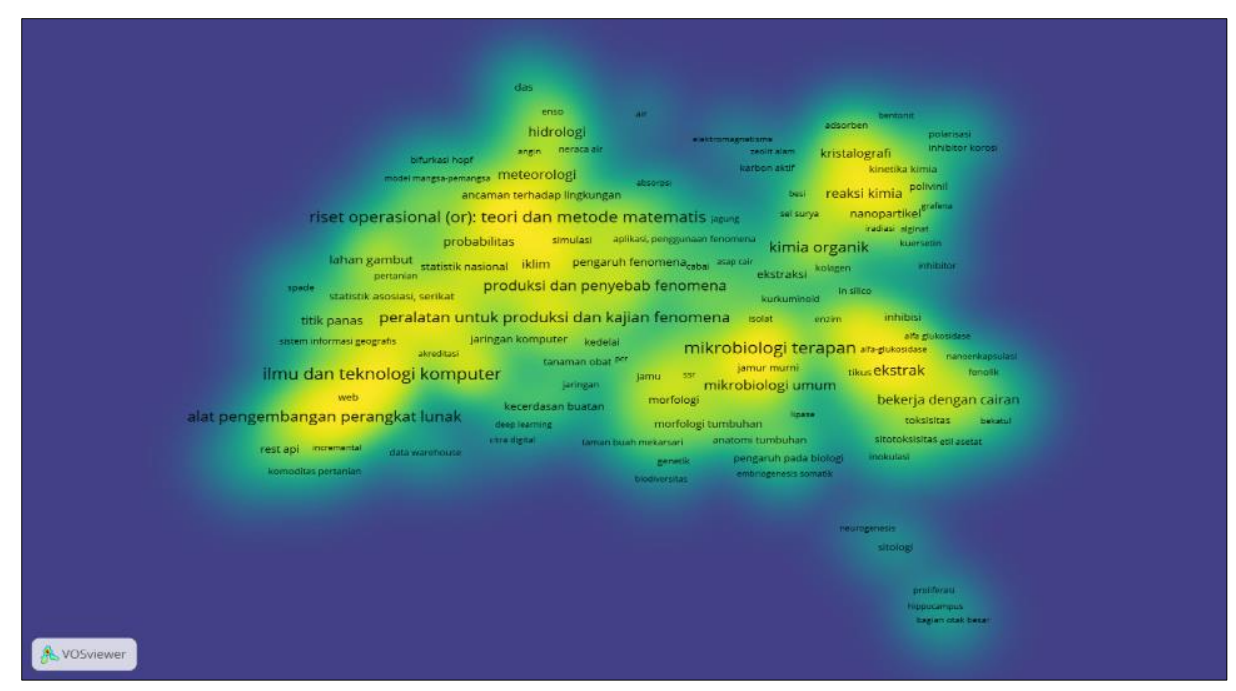

Gambar 9. Visualisasi Kepadatan Kata Kunci

Gambar 9. Mengilustrasikan penelitian ini memberikan informasi visualisasi kepadatan kata kunci hasil analisis Program VosViewer Versi 1.6.1.5 dimana terdapat 12 gugus (cluster) kata kunci yang sangat menonjol antara satu kata kunci dengan kata kunci lain, dan terlihat jelas berukuran lebih besar dari kata kunci lain disekitarnya, disertai latar belakang warna yang lebih terang.
Visualisasi tersebut sebenarnya menandakan bahwa ada kecenderungan (trend) volume penelitian terhadap kata kunci tersebut yang padat, sebagaimana terlihat pada warna latar belakang teks tulisan kata kunci yang lebih terang pada Gambar 12. Visualisasi Kepadatan Kata Kunci.

Penelitian ini melaporkan telah menemukan sekurangnya 12 gugus (cluster) kata kunci pada skripsi Fakultas 
Matematika dan Ilmu Pengetahuan Alam IPB University lulusan Tahun 2015 sampai dengan Tahun 2019 dengan kecenderungan (trend) volume penelitian untuk kata kunci tersebut yang pernah dan mungkin sangat sering dilakukan. Informasi sebaran kecenderungan (trend) volume peneli-tian tersebut bisa dilihat pada Tabel 7 berikut.

Tabel 7 Sebaran Kecenderungan (trend) Volume Penelitian Skripsi FMIPA Lulusan Tahun 2015 sampai dengan Tahun 2019

\begin{tabular}{llccc}
\hline Kelas & Kata kunci & $\begin{array}{c}\text { Gugus } \\
\text { (Cluster) }\end{array}$ & $\begin{array}{c}\text { Tahun } \\
\text { Penelitian }\end{array}$ & $\begin{array}{c}\text { Volume } \\
\text { Penelitian }\end{array}$ \\
\hline $\mathbf{0 0 4}$ & Ilmu dan teknologi komputer & 5 & 2017 & Sangat Padat \\
$\mathbf{5 7 9 . 4}$ & Mikrobiologi terapan & 8 & 2017 & Sangat Padat \\
$\mathbf{5 1 9 . 8}$ & Riset operasi (OR): Metode dan matematis & 1 & 2017 & Sangat Padat \\
$\mathbf{5 4 7}$ & Kimia organik & 2 & 2017 & Tidak Padat \\
$\mathbf{0 0 4 . 4}$ & Alat pengembangan perangkat lunak & 6 & 2018 & Sangat Padat \\
$\mathbf{5 7 7}$ & Dasar alami kehidupan & 3 & 2017 & Sangat Padat \\
$\mathbf{5 5 1 . 5 8}$ & Klimatologi & 4 & 2017 & Sangat Padat \\
$\mathbf{5 7 9 . 2}$ & Mikro biologi umum & 7 & 2017 & Cukup Padat \\
$\mathbf{5 4 . 0 8}$ & Metode & 9 & 2017 & Cukup Padat \\
$\mathbf{5 4 2 . 9}$ & Sitologi & 11 & 2017 & Tidak Padat \\
$\mathbf{5 4 9 . 7}$ & Senyawa lain - [asamoksida] & 10 & 2016 & Sangat Padat \\
$\mathbf{0 0 4 . 6 5}$ & Data warehouse - gudang data] & 12 & 2017 & Tidak Padat \\
\hline
\end{tabular}

Penelitian ini melaporkan bahwa ada sekitar 7 kata kunci yang bisa diketahui kecenderungan (trend) volume kepadatan penelitiannya pada skripsi FMIPA IPB University lulusan tahun 2015 sampai dengan tahun 2019. Kata kunci tersebut diantaranya adalah sebagaimana bisa dilihat pada daftar Tabel 7 tersebut di atas.

Tabel 7. Mengilustrasikan bahwa sebaran kecenderungan (trend) volume penelitian pada skripsi Fakultas Matematika dan Ilmu Pengetahuan Alam IPB University lulusan tahun 2015 sampai dengan tahun 2019 yang bisa dijelaskan bahwa, Ilmu dan teknologi komputer (004) ada pada gugus 5 dengan 397 tautan pernah diteliti tahun 2017 sangat padat; Mikrobiologi terapan (579.4) ada pada gugus 8 dengan 237 tautan pernah diteliti tahun 2017 sangat padat; Riset operasi (OR): Metode dan matematis (579.4) ada pada gugus 1 dengan 207 tautan pernah diteliti tahun 2017 sangat padat; Kimia organik (547) ada pada gugus 2 dengan 240 tautan pernah diteliti tahun 2017 tidak padat; Alat pengembangan perangkat lunak (004.4) ada pada gugus 6 dengan 297 tautan pernah diteliti tahun 2018 sangat padat; Dasar alami kehidupan (577) ada pada gugus 3 dengan 314 tautan pernah diteliti tahun 2017 sangat padat;
Klimatologi (551.58) ada pada gugus 4 dengan 229 tautan pernah diteliti tahun 2017 sangat padat; Mikro biologi umum (579.2) ada pada gugus 7 dengan 117 tautan pernah diteliti tahun 2017 cukup padat; Metode (54.08) ada pada gugus 9 dengan 116 tautan pernah diteliti tahun ; Sitologi (542.9) ada pada gugus 11 dengan 60 tautan pernah diteliti tahun 2017 cukup padat; Senyawa lain [asamoksida] (549.7) ada pada gugus 10 dengan 57 tautan pernah diteliti tahun 2016 sangat padat; Data warehouse [gudang data] (004.65) ada pada gugus 12 dengan 43 tautan pernah diteliti tahun 2017 tidak padat.

\section{Produktivitas Dosen \\ Pembimbing}

Produktivitas dosen pembimbing ditentukan berdasarkan sebaran jumlah bimbingan penelitian pada skripsi Fakultas Matematika dan Ilmu Pengetahuan Alam (FMIPA) tahun 2015 sampai dengan 2019. Hasil penelitian menunjukan bahwa tingkat

produktivitas untuk setiap dosen berbeda-beda, sesuai peranan masingmasing dalam melakukan pembimbingan skripsi tersebut. Peranan dosen pembimbing skripsi tersebut ada sebagai pembimbing kesatu; dan pembimbing kedua; serta sebagai pembimbing ketiga. 
Tabel 8 Sebaran Jumlah Pembimbing Kesatu Skripsi FMIPA

Lulusan Tahun 2015 sampai dengan 2019

\begin{tabular}{clc}
\hline No. & \multicolumn{1}{c}{ Dosen Pembimbing } & Jumlah Bimbingan \\
\hline 1 & Imas Sukaesih Sitanggang & 79 \\
2 & Firman Ardiansyah & 53 \\
3 & Wisnu Ananta Kusuma & 52 \\
4 & Rina Trisminingsih & 44 \\
5 & Meuthia Rachmaniah & 41 \\
6 & Irzaman & 39 \\
7 & Dean Apriana Ramadhan & 38 \\
8 & Irman Hermadi & 37 \\
9 & Mega Safithri & 35 \\
10 & Maria Bintang & 35 \\
\hline
\end{tabular}

Informasi yang diperoleh dari ilustrasi Tabel 8. tersebut di atas adalah sebaran jumlah bimbingan skripsi terbanyak oleh sepuluh orang dosen sebagai pembimbing kesatu pada skripsi Fakultas Matematika dan Ilmu Pengetahuan Alam IPB University lulusan tahun 2015 sampai dengan 2019. Jumlah bimbingan terbanyak pertama ialah Imas Sukaesih Sitanggang dengan jumlah bimbingan yang telah dilakukan sebanyak 79 bimbingan skripsi. Jumlah bimbingan terbanyak kedua dan ketiga ialah Firman Ardiansyah dan Wisnu Ananta Kusuma dengan jumlah bimbingan yang telah dilakukan masing-masing sebanyak 53 dan 52 bimbingan.

Kemudian disusul oleh Rina Trisminingsih, Meuthia Rachmaniah, dan Irzaman, serta Dea Apriana Ramadhan dengan masing-masing jumlah bimbingan skripsi yang telah dilakukan sebanyak 44, 41, dan 39, serta 39 bimbingan. Selanjutnya menyusul dengan jumlah bimbingan skripsi yang relatif sedikit dari yang telah disebutkan sebelumnya ialah Irman Hermadi dan Maria Bintang, serta Mega Safithri yang telah melakukan bimbingan sebanyak masing-masing 37, dan masing-masing sama juga yaitu 35 bimbingan skripsi.

Tabel 9 Sebaran Jumlah Pembimbing Kedua Skripsi FMIPA Lulusan Tahun 2015 sampai dengan 2019

\begin{tabular}{clc}
\hline No. & \multicolumn{1}{c}{ Dosen Pembimbing } & Jumlah Bimbingan \\
\hline 1 & Ali Kusnanto & 42 \\
2 & Mohammad Khotib & 41 \\
3 & Dimas Andrianto & 39 \\
4 & Mohamad Rafi & 35 \\
5 & Wulan Tri Wahyuni & 28 \\
6 & Farida Hanum & 28 \\
7 & Cici Suhaeni & 26 \\
8 & Ruhiyat & 26 \\
9 & Hadi Sumarno & 24 \\
10 & Laksmi Ambarsari & 23 \\
\hline
\end{tabular}

Informasi yang diperoleh dari ilustrasi Tabel 9. tersebut di atas adalah sebaran jumlah bimbingan skripsi terbanyak oleh sepuluh orang dosen sebagai pembimbing kedua pada skripsi FMIPA IPB University lulusan tahun 2015 sampai dengan 2019. Jumlah bimbingan terbanyak pertama ialah Ali Kusnanto dengan jumlah bimbingan yang telah dilakukan sebanyak 42 bimbingan skripsi. Jumlah bimbingan terbanyak kedua dan ketiga ialah Mohammad Khotib dan
Dimas Andrianto dengan jumlah bimbingan yang telah dilakukan sebanyak 41 dan 39 bimbingan. Kemudian disusul oleh Mohamad Rafi, Farida Hanum, dan Wulan Tri Wahyuni, serta Ruhiyat dengan masingmasing jumlah bimbingan skripsi yang telah dilakukan sebanyak 35,28 , dan sama 28, serta 26 bimbingan. Selanjutnya menyusul dengan jumlah bimbingan skripsi yang relatif sedikit dari yang telah disebutkan sebelumnya 
ialah Cici Suhaeni dan Hadi Sumarno, serta Laksmi Ambarsari yang telah melakukan bimbingan sebanyak masingmasing 26, 24, dan sama juga yaitu 23 bimbingan skripsi.
Informasi produktivitas dosen sebagai pembimbing ketiga bisa dilihat Gambar 12. sebagaimana berikut.

Tabel 10 Sebaran Jumlah Pembimbing Ketiga Skripsi FMIPA

Lulusan Tahun 2015 sampai dengan 2019

\begin{tabular}{clc}
\hline No. & \multicolumn{1}{c}{ Dosen Pembimbing } & Jumlah Bimbingan \\
\hline 1 & Budi Waryanto & 8 \\
2 & Etih Sudarnika & 5 \\
3 & Noriaki Sasai & 5 \\
4 & Dimas Andrianto & 4 \\
5 & Agus Setiyono & 3 \\
6 & Yani Nurhadryani & 3 \\
7 & Waras Nurcholis & 3 \\
8 & Laksmi Ambarsari & 3 \\
9 & Erfiani & 2 \\
10 & Bimandra Adiputra Djaafara & 2 \\
\hline
\end{tabular}

Informasi yang diperoleh dari ilustrasi Tabel 10. mengilustrasikan sebaran jumlah bimbingan skripsi terbanyak oleh sepuluh orang dosen sebagai pembimbing ketiga pada skripsi Fakultas Matematika dan Ilmu Pengetahuan Alam IPB University lulusan tahun 2015 sampai dengan 2019. Adapun jumlah bimbingan terbanyak pertama ialah Budi Waryanto dengan jumlah bimbingan yang telah dilakukan sebanyak 8 bimbingan skripsi. Jumlah bimbingan terbanyak kedua dan ketiga ialah Noriaki Sasai dan Etih Sudarnika dengan jumlah bimbingan yang telah dilakukan sebanyak 5 dan sama 5 bimbingan. Kemudian disusul oleh Dimas Andrianto, Laksmi Ambarsari, dan Waras Nurcholis, serta Yani Nurhadryani dengan masing-masing jumlah bimbingan skripsi yang telah dilakukan sebanyak 4, 3, dan sama 3, serta 3 bimbingan. Selanjutnya menyusul dengan jumlah bimbingan skripsi yang relatif sedikit dari yang telah disebutkan sebelumnya ialah Agus Setiyono dan Bimandra Adiputra Djaafara, serta Erfiani yang telah melakukan bimbingan sebanyak masing-masing 3, 2, dan sama juga yaitu 2 bimbingan skripsi.

\section{Kesimpulan}

Berdasarkan uraian hasil dan pembahasan penelitian yang telah diuraikan, maka diperoleh beberapa kesimpulan sebagai berikut :

1. Topik penelitian paling banyak berdasarkan Universal Decimal Classification (UDC) pada kelas 004 terkait "Ilmu dan
Teknologi Komputer. Komputasi. dan Pemrosesan data" sebanyak 719 judul (20,25\%), sedangkan topik penelitian paling sedikit kelas 590 terkait "Zoologi" sebanyak 43 judul $(1,21 \%)$.

2. Analisis kata kunci menggunakan Vosviewer versi 1.6.1.5 pada kemunculan kata kunci minimum 5 kali berhasil memvisualisasikan 683 kata kunci dalam 12 gugus (cluster). Kata kunci paling banyak muncul terjadi ada pada gugus (cluster) 5 yaitu "Ilmu dan Teknologi Komputer" 153 kali dengan total tautan jaringan (total network link) 397.

3. Kecenderunagan (trend) topik penelitian paling banyak diminati: "Ilmu dan Teknologi Komputer", dan tahun penelitian pernah dilakukan tahun 2016-2018, dengan kepadatan volume penelitian berpariasi.

4. Dosen pembimbing skripsi utama paling produktif ialah Imas Sukaesih Sitanggang sebanyak 79 bimbingan, sedangkan pembimbing anggota paling produktif ialah Ali Kusnanto dan Budi Waryanto dengan jumlah bimbingan masing-masing sebanyak 42 dan 8 bimbingan.

\section{Daftar Pustaka}

Helmi, Machdar. (2014, November 28). Machdarhelmi. Dipetik Pebruari 25, 2020, dari Pengertian skripsi, tesis, disertasi, karangan ilmiah populer dan jurnal: https:/ / machdarhelmi. wordpress.com/2014/11/28/pengertian- 
skripsi-tesis-disertasi-karangan-ilmiah-populerjurnal/

Pattah, Sitti Husaebah. (2013). Pemanfaatan kajian bibliometrika sebagai metode evaluasi dan kajian dalam ilmu perpustakaan dan informasi. Khizanah Al-Hikmah vol. 1 nomor 1, Januari 2013, hal. 47-57, 1(1), 47-57

Ratnaningsih, \& Himawan, D. (2016). Peningkatan Layanan Data dan Informasi dalam rangka Memenubi Kebutuban Informasi di Perpustakaan Perguruan Tinggi (Suatu kajian deskriptif analisis terhadap 5 bunga komersial utama dan 7 bunga potensial komersial). Dipetik May 18, 2019, dari IPB Scientific Repository: https:// repository.ipb.ac.id/handle/12345678 9/93672

Ratnantingsih, Himawan, D., \& Saleh, A. (2019). Peta penelitian terhadap 12 buah lokal Indonesia pada skripsi, tesis dan disertasi lulusan IPB . Visi Pustaka vol. 19 nomor 3, Desember 2017, hal. 191-201, 19(3), 191-201

Saleh, A. (2018). Potret Penelitian Skripsi Fakultas Peternakan IPB lulusan tahun 2012. 2016: Sebuab kajian pemetaan bidang ilmu pada penelitian mahasiswa Fakultas Peternakan IPB. Dipetik May 18, 2019, dari Researchgate.net:

Saleh, A., Himawan (2019). Pemetaan bidang ilmu pada skripsi fakultas perikanan lulusan tabun 2014-2018 berdasarkan standar Universal Decimal Classification

Sugiyono. (2014). Metode Penelitian Manajemen: Pendekatan kuantitatif, kualitatif, kombinasi, penelitian tindakan, penelitian evaluasi. Bandung: Alfabeta

Sulistyo-Basuki. (1991). Pengantar ilmu perpustakaan. Jakarta: Gramedia Pustaka Utama. 